\title{
Article
}

\section{The future of mental health nursing: are we barking up the wrong tree?}

McKeown, Mick and White, Jacquie

Available at http://clok.uclan.ac.uk/11929/

McKeown, Mick ORCID: 0000-0003-0235-1923 and White, Jacquie (2015) The future of mental health nursing: are we barking up the wrong tree? Journal of Psychiatric and Mental Health Nursing, 22 (9). pp. 724-730.

It is advisable to refer to the publisher's version if you intend to cite from the work. http://dx.doi.org/10.1111/jpm.12247

For more information about UCLan's research in this area go to

http://www.uclan.ac.uk/researchgroups/ and search for < name of research Group>.

For information about Research generally at UCLan please go to http://www.uclan.ac.uk/research/

All outputs in CLoK are protected by Intellectual Property Rights law, including Copyright law. Copyright, IPR and Moral Rights for the works on this site are retained by the individual authors and/or other copyright owners. Terms and conditions for use of this material are defined in the policies page.

\section{CLoK}

Central Lancashire online Knowledge www.clok.uclan.ac.uk

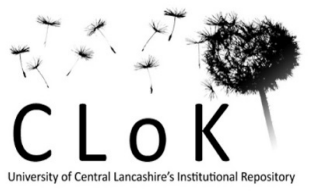




\section{The future of mental health nursing: are we barking up the wrong tree?}

\section{Introduction}

This commentary has been prompted by a degree of disquiet amongst the UK mental health nursing community in response to the Shape of Caring Review on the future of nurse education in England (Willis 2015). Proposals for the structure of nurse education have been interpreted as emphasising generic at the expense of field specific (e.g. mental health) education, with much specialist training beyond the scope of pre-registration courses (Lintern 2014, Middleton 2015). Specifically, there is a suggestion that student nurses will not enter their specialised field until completing two years of more generalist learning; reminiscent of the previous Project 2000 approach, criticised for supposed inadequate preparation of mental health students because general adult nursing dominated curriculum and teaching (UKCC 1999).

This has precipitated an amount of breast-beating, soul-searching, and vociferous protestation about the future, if not the survival, of mental health nursing as a distinct discipline (see MHNAUK 2014, 2015). Moreover, we have been here before, with previous critical debate regarding the role of nurses in mental health services and the appropriateness of different approaches to education (Callaghan \& Owen 2005). Insufficient attention to mental health concepts and competencies in the Australian model of comprehensive (generic) nurse training has resulted in an inadequately skilled workforce (McAllister et al. 2014). In this context, a need for change can be acknowledged but it is highly questionable that a turn to genericism offers the solution (Ion \& Lauder 2015).

Whilst emphasising a commitment to the value of good mental health nursing, we contend that getting drawn into debate solely framed by Willis, limited to uncritical views of workforce planning and curriculum, is a distraction from more serious issues. Notwithstanding this, consideration of other perspectives on the future of the mental health nursing workforce is 
merited. Indeed, there are persuasive arguments in favour of some aspects of curriculum revision and workforce reorganisation, as highlighted by Willis but also flowing from a more radical critique. In this context, nursing faces various crises of legitimacy, aspects of which, after all, prompted Willis's scrutiny in the first place. Mental health nursing, along with other psy-professions (Ingleby 1985), arguably needs to address fundamental challenges that certainly require much more substantial transformation than anticipated by Willis. Ultimately, we argue that an uncritical or knee-jerk response to the Shape of Caring Review would be misplaced and neglect more important considerations.

We draw upon the sociology of work and a critique of mental health nursing's professionalisation project to demonstrate how successive governments and employers have under-valued nursing through strategies of deskilling and degradation of their work. If we consider mental health nursing as a form of work or occupation like any other, then reflection on nursing as work and how this work is organised (the labour process) offers numerous insightful observations relevant to making sense of the Willis proposals and reaction to them. This, in turn, opens up consideration of strategies of resistance or more palatable alternatives that address legitimacy deficits.

We look forward to a future for mental health nursing that moves beyond concerns with the structure of training and education to focus, instead, on the actual form of progressive mental health care and the learning needed to underpin this. We make our argument with recourse to three notable threats to mental health nursing's legitimacy: an alleged failure of compassion; the scandal of unmet physical health needs amongst people with serious mental health problems; and the attachment of mental health nursing to a psychiatric episteme. In terms of a specific mental health nursing focus, Willis is silent on the first and third of these legitimacy crises, but does make a strong case for holistic models of care implicit in preferred solutions to the second. 


\section{The crises facing mental health nursing: I. Compassion deficit}

The history of mental health care is as much littered with outrageous abuse, neglect and poor care and treatment as it is with celebrations of high quality therapeutic relations (Hopton 1997). Events at Winterbourne View Hospital demonstrated that recent times are not immune from this disrepute (Department of Health 2012). The anomalous care and treatment of minorities within historical and contemporary psychiatric services also to some extent speaks of compassion deficits (Keating et al. 2002). These obvious examples and more subtle issues at the relational level are partly explained by processes of othering, whereby individuals are conceived of and constructed as distinctly alien or different (MacCallum 2002). Service user and survivor critics have long bemoaned a perceived distance, proximal and emotional, in their engagement with services (Grant et al. 2011, Newnes et al. 1999, 2001, Rogers et al. 1993). Current workforce pressures, combined with a preponderance of administrative tasks, further separates nursing staff from service users, especially in inpatient settings (McAndrew et al. 2014, Whittington \& McLaughlin 2000).

Contemporary mental health services in the UK are arguably defined in terms of compulsion and coercion, inevitably complicating therapeutic relations (Duxbury 2015, Wyder et al. 2013). Last year, in England and Wales, over 53,000 individuals were subject to compulsion under the Mental Health Act, the largest figure ever (Care Quality Commission [CQC] 2014). Numbers subject to Community Treatment Orders have also substantially risen but without the intended reduction in compelled hospital admissions (Burns et al. 2013). Most inpatient units operate at high levels of bed occupancy, with a minority exceeding 120\% (CQC 2012); whilst the Royal College of Psychiatrists (2011) contend that quality of care is compromised above $85 \%$. For the CQC (2012), this state of affairs suggests that the management of containment and control is squeezing out possibilities to deliver the more positive aspirations of national policy. Unfortunately, many service users have a negative experience of compulsory admissions to care, and it is mental health nurses who are in the front line of dealing with this (Katsakou et al. 2012, Katsakou \& Priebe 2007, Sapey 2013, Sibitz et al. 
2011). The relationships that nurses are able to forge with service users are undoubtedly influenced by these organisational factors, and it is these relational connections, good or bad, that will primarily impact upon service users' views of the service as a whole.

\section{The crises facing mental health nursing: II. Neglect of physical healthcare}

Numerous reports and policy pronouncements recognise a substantial increased risk of mortality and morbidity associated with preventable physical disease amongst individuals identified as psychiatric patients (Latoo et al. 2013, Leucht et al. 2007). Despite other disciplines, such as General Practitioners, needing to play a key role, the input of nursing has been highlighted in support and prevention (Blythe \& White 2012, Happell et al. 2014). The flip-side is also true, many non-psychiatrically identified patients have substantial unmet emotional and psychic needs associated with the experience of physical ill-health (Naylor et al. 2012). A more holistic approach to care across the board would undoubtedly be beneficial.

Research shows mental health nurses are motivated to address physical health needs of the most vulnerable individuals (Robson et al. 2012, Happell et al. 2014). However, unacceptably low levels of physical health monitoring and intervention in mental health care in England and Wales continue to be reported (Royal College of Psychiatrists 2012, 2014) This may be because of the way caseloads are managed: the service being increasingly restricted to those deemed in crisis. Input around medicines administration frames the workload of the most junior colleagues. Hence, personalised interventions for physical health and lifestyle changes are prevented by the way that the work is organised.

\section{The crises facing mental health nursing: III. Complicity with iatrogenic bio-psychiatry} An amalgam of service user/survivor critics, other external voices, and critically minded practitioners, argue that psychiatry itself causes harm and is inescapably bound up with 
systems of social control (Crossley \& Crossley 2001, Miller \& Rose 1986, Rogers \& Pilgrim 2014). The emergence of organised service user, oft-styled survivor, movements pose a serious challenge to the legitimacy of psychiatry and associated groups such as mental health nurses. There is no single movement or political doctrine, with demands ranging from simply having one's voice heard within services to radical transformations of the system, including its complete dismantlement (Campbell 2009). Due attention to the nature and implications of these challenges are central to any consideration of the future value of mental health nursing. Arguably, psychiatry has been adept at co-opting elements of external critique whilst continuing to maintain a fairly consistent biological approach to care and treatment.

Essentially, services stand accused of uncritical fidelity to an overly simplistic medical model of mental distress, neglecting more socially or relationally framed alternatives. Psychiatric medication, in particular, is criticised for a weak conceptual and evidentiary base and is implicated in the aforementioned serious physical health detriment and levels of chronicity of mental distress (Foley \& Morley 2011, Moncreiff et al. 2013, Whittaker 2010). This is a very important set of criticisms, as mental health nurses are in the forefront of medication administration and encouraging compliance, and, for many service users this defines their role. Similarly, a perception that services are risk averse puts nurses in a central position of managing the impact of systemic denial of rights and liberties, such that nurses, however good their relational skills, become identified with compulsion and coercion (Gilburt et al. 2013). They are also more often than not the first to be blamed when risk management goes wrong, which reinforces tendencies for risk aversion (Pilgrim 2012).

Mental health nursing's subordinate relationship to bio-psychiatry is thus reflected in both the organisation of services and the experience of receiving care. From a critical perspective, recent organisational attempts to adopt the notion of recovery, itself informed by survivor critique, runs the risk of being incorporated or adulterated within the psychiatric frame 
(Pilgrim 2008, Pilgrim \& McCranie 2013). Latterly, a very interesting critique posits that the various inequities most keenly felt by service users are explicable primarily in terms of underpinning knowledge: forms of epistemic injustice or, in the extreme, epistemic violence (Fricker 2007, Russo \& Beresford 2014). A challenge for mental health nurses who themselves are critical of the dominance of simple bio-psychiatry is how to assert, or reassert, forms of social, relational, psychological or humanistic knowledge, for example, that might inform alternative approaches.

\section{Nursing as work: the mental health care labour process}

To address perceived problems with nursing practice it is important to focus on how nursing work is organised. Historically, the work of Frederick Winslow Taylor (1911) was pivotal in introducing scientific management of the labour process. Taylorism ushered in so-called time and motion studies and a new era of Fordism, typified by increasingly alienated workforces. The classic alienating labour process is the production line, first introduced by Henry Ford, where single workers undertake only the simplest of tasks and have no control over work planning or even basic things, like the pace at which the line moves. Plainly, such developments were made possible by novel technologies of mass production, and the history of alienation is intimately entangled with the implementation of newer and newer technologies in a creeping degradation of the very experience of work (Braverman 1974). The Luddites, thus, were not merely philistine destructors of weaving equipment. They were protesting the loss of an old way of life, that was bound up with sense of community, and, crucially, had offered workers a greater degree of control over their work.

A number of commentators have addressed the organisation of nursing and other health and social care work in these terms, arguing that a fragmentation of tasks and diminishment of autonomy and job satisfaction is being enacted as this work is subject to new forms of technology and managerialism (Dykes 2006, McKeown 1995). These means for transforming nurses' work can also be seen to be a convenient weapon in turning aside 
claims for a more esteemed professional identity. Breaking down work that was previously a 'nursing process', with individual practitioners involving themselves in planning, execution and evaluation of a complete range of interventions, into a larger number of disparate tasks, spread around the workforce, massively denudes the extent to which all nurses can display autonomy. The aggregate effect undermines rhetorical commitment to holistic care and seeds the alienation of both staff and service users. For cost conscious employers, there are savings to be made, at least in the short term, in re-calibration of skill-mixes between registered and non-registered nurses, and role substitution at both the top and bottom of the nursing grade pyramid: with health care assistants increasingly taking on tasks previously only undertaken by registrants, and senior nurses undertaking some junior medical roles (Skills for Health 2006).

\section{The quest for professionalization: Holy Grail or fool's errand?}

Matters of control and autonomy within the labour process are intimately associated with claims for a professional identity. Professionalised or professionalising occupations operate a number of strategies to gain and then hold an advantageous position in the labour market (Etzioni 1969). These typically involve tactics to restrict entry to the profession, claiming a unique body of underpinning knowledge, accrediting training and stipulating competencies (Freidson 1970, Witz 1990). Classically, these forms of occupational closure, coupled with tactics of mystification and specialised language, have the effect of maintaining high esteem, wages and a privileged social position for professionals. Of course, nursing's claims to full professional status are very much open to debate. Because the scale of the task requires a large workforce, aspects of their work are seen as mere domestic or menial labour, and they occupy a field of practice that already contains an established professional group, doctors, the semi-professional label has been applied (Etzioni 1969, Witz 1990). Beyond knowledge claims, a full professional identity usually comes with a significant degree of control over working pattern, the everyday process of the work, and the volume of work to be undertaken. 
Once we understand mental health nursing's predicament through the lens of professionalization and labour process, we can spot how relevant language inevitably leaks into the discourse of both the proposals and resistance to them. Willis speaks explicitly of career pathways, professionalization and 'silo working' (Lintern 2014, Willis 2015). Mental Health Nurse Academics UK $(2014,2015)$, reasonably point to concerns over 'dilution' of 'specialist knowledge and skills' and hint at antipathy to the 'cold clinical world' of 'technology'. All of this vocabulary is replete with archetypal anxieties attached to professionalization, the struggle for more control and autonomy in the workplace, and, indeed, a plea to be involved in shaping implementation of the proposals. In this regard, Middleton's (2015) Nursing Times editorial asserts a distinctly professionalised call to arms:

Can you imagine doctors meekly acquiescing to an independent review on their education? They would challenge, take on board and adopt if they felt it would increase their standing. Nursing should do the same.

\section{Who's alienating who?}

Generally speaking, workers who lack control over different aspects of their work suffer alienation. From this perspective, the ultimate non-alienating jobs belong to craft workers, maintaining responsibility for all aspects of the job, from start to finish. Alienated labour processes minimise the extent to which any single worker has much autonomy or control over how the work is organised, and usually under capitalism, somebody else takes the value of what is produced (Marx 1844: 1977). Technologies drove the industrial revolution and then served it, and the associated growth of urbanisation, by providing for new approaches to production. It is arguably no coincidence that urban environments are significantly associated with high levels of mental distress (Fitzgerald et al. 2014), and this in turn is fairly obviously linked to capitalistic ownership, concentrating wealth with a minority (Wilkinson \& Pickett 2009). 
For Marx, a fundamental source of alienation derives from a notion of 'species being'. To be denied opportunity to express one's innate sense of commitment to, and fellowship with, other human beings presents a powerful form of psychic damage, and connects with our current concerns with compassionate care (Spandler \& Stickley 2011). Arguably, the aforementioned degradation of nursing work can only negatively impact upon our 'species being': our wishes to care for others, especially those in distress, and to hold onto an identity that so-defines us. From the over-use of medication to novel computerised therapies, the experience of psychiatric care is critically characterised by largely impersonal technological interventions. Erich Fromm's (1968: 1973) critique from the 1960s could equally apply to much of mental health care today, with alienated practitioners, compounding the alienation of the mentally distressed by the application of alienating technologies.

\section{Possible futures}

An increasingly atomised, alienated mental health nursing need not be the only possible future, and resistance to the march of alienating technologies and managerialism could be mutually beneficial to both service users and mental health nurses, opening up a raft of possibilities. Thinking further about the mechanisms of alienation affords consideration of the human, relational dimensions of the alienated condition and points to purposively relational solutions. There are alternative approaches for organising work, and some of these might be most suited to the sort of public service settings within which nurses' work takes place. One such model that protects autonomy, and nursing could be well-placed to adopt, is flexible specialisation (McKeown 1995, Piore \& Sabel 1984). Better still, replacement labour processes could be framed within more inclusive systems of cooperation and democracy (McKeown \& Carey 2015) and embrace alternatives to bio-psychiatry, such as Soteria or Open Dialogue. Both of these forms of intervention address care and treatment of individuals who would typically be diagnosed with psychosis and deliver positive outcomes compared 
with standard psychiatric care (Aaltonen et al. 2011, Calton et al. 2008, Seikkula et al. 2011). The Soteria approach developed by Lauren Mosher in the 1970s shares some characteristics of therapeutic communities, providing a calming environment, equalised relationships between staff and residents, and minimal or no usage of psychotropic medication (Mosher 1999). Open Dialogue, which has latterly emerged in Finland and is gaining interest in the UK, brings together service users and their families with clinicians who apply a particular form of communicative dialogue to collaboratively make sense of experiences (Seikkula \& Olson 2003).

Peter Sedgwick in his seminal text Psychopolitics (1982) stressed the endemic extent of mental distress in modern urbanised societies and the ultimate necessity for the State to marshal appropriate resources to provide meaningful support. Sedgwick looked for alliances between health care workers and service users to press for progressive change and alternative models of care. He saw problems inherent in the task of transforming mental health services as essentially similar to the challenge of liberating society as a whole: in effect wishing for an 'organised and socialised humanity' (p256). In this sense, the need for mental health nursing to lay claim to a renewed legitimacy could be a key driver for achieving these worthwhile objectives: it need not deny the prevalence of mental ill-health and is likely best served in solidarity with service user movements.

\section{Conclusions}

Even if the Willis proposals appear to come from a benign place, and in some regards make sense, governments bent on cost cutting and shrinking the state may pounce on them for other ends. Reflection upon epistemic criticisms of mental health nursing interacts with wider consideration of identity, role and professional status, and we have explored these with a view to illuminating debates about future occupational and workforce strategies. We really need to defend the value of nurses' work and make the case that this is rewarded 
commensurately and allowed to thrive within work contexts in which colleagues and service users have much more democratic voice in how the actual work is organised. If we take the initiative, playing to the undoubted strengths of nursing, this could result in transformed working environments and labour process, such that relational elements of care displace biomedical technologies. Education would then have to be organised to best prepare and socialise nurses into these new democratised forms of care work. We think it is in this direction we ought to travel, and any simplistic reaction to Willis may be an act of barking up the wrong tree.

Our challenge is to critically debate the issues, raised within and without our ranks, and arrive at adequate responses, simultaneously resisting attempts to dismantle mental health nursing as a valued occupation. Survivor movements may agree that deliberating over change is one thing, but trying to get something back once it is gone is a much harder task. Let us, with humility (Brandon 1991), defend mental health nursing and maintain large numbers in direct practice but, ultimately, let us build alliances concerned with re-shaping what we do to escape the narrow and alienating confines of much of this work as we now know it. 


\section{References}

Aaltonen, J., Seikkula, J. \& Lehtinen, K. (2011): The Comprehensive Open-Dialogue Approach in Western Lapland: I. The incidence of non-affective psychosis and prodromal states. Psychosis: Psychological, Social and Integrative Approaches, 3, 3, 179-191.

Blythe, J., \& White, J. (2012) Role of the mental health nurse towards physical health care in serious mental illness: An integrative review of 10 years of UK literature. International Journal of Mental Health Nursing, 21, 3, 193-201.

Brandon, D. (1991) Innovation without change?: consumer power in psychiatric services. Macmillan, Basingstoke.

Braverman, H. (1974). Labor and Monopoly Capital: The Degradation of Work in the Twentieth Century. Monthly Review Press, New York.

Burns, T., Rugkåsa, J., Molodynski, A., Dawson, J., Yeeles, K., Vazquez-Montes, M., Voysey, M., Sinclair, J. \& Priebe, S. (2013) Community treatment orders for patients with psychosis (OCTET): a randomised controlled trial. The Lancet, 381, 9878, 1627-1633.

Callaghan, P. \& Owen, S. (2005) Psychiatric and mental health nursing: past, present and future. Journal of Psychiatric and Mental Health Nursing, 12, 639-641.

Calton, T., Ferriter, M., Huband, N., \& Spandler, H. (2008). A systematic review of the Soteria paradigm for the treatment of people diagnosed with schizophrenia. Schizophrenia Bulletin, 34, 1, 181-192. 
Campbell, P. (2009) The service user/survivor movement. in J. Reynolds, R. Muston, T. Heller, J. Leach, M. McCormick, J. Wallcraft and M. Walsh (eds) Mental health still matters. Palgrave Macmillan/Open University Press, Basingstoke/Milton Keynes. pp. 46-52.

Care Quality Commission. (2012) Mental Health Act Annual Report 2011/12. CQC, Newcastle.

Care Quality Commission (2014) Monitoring the Mental Health Act in 2013/14. CQC, Newcastle.

Crossley, M. L., \& Crossley, N. (2001) Patient'voices, social movements and the habitus; how psychiatric survivors 'speak out'. Social Science \& Medicine, 52, 10, 1477-1489.

Department of Health (2012) Transforming care: A national response to Winterbourne View Hospital - Final review Report. Department of Health, London.

Duxbury, J. (2015) The Eileen Skellern Lecture 2014. Physical restraint: in defence of the indefensible?. Journal of Psychiatric and Mental Health Nursing, 22, 2, 92-101.

Dykes, F. (2006) Breastfeeding in hospital: Mothers, midwives and the production line. Routledge, London. 
Etzioni, A. (1969) The Semi-Professions and Their Organization. Free Press, New York.

Fitzgerald, D., Rose, N. \& Singh, I. (2014) Urban life and mental health: Re-visiting politics, society and biology. Discover Society, 5, http://www.discoversociety.org/2014/02/15/urbanlife-and-mental-health-re-visiting-politics-society-and-biology/ accessed 21.03.15

Foley, D. L., Morley, K. I. (2011) Systematic Review of Early Cardiometabolic Outcomes of the First Treated Episode of Psychosis. Arch Gen Psychiatry, 68, 609-616. doi:10.1001/archgenpsychiatry.2011.2

Freidson E. (1970) Profession of Medicine: A Study of the Sociology of Applied Knowledge. Harper \& Row, New York.

Fricker, M. (2007) Epistemic Injustice: Power and the Ethics of Knowing. Oxford University Press, Oxford.

Fromm, E. (1968) Marx's contribution to the knowledge of man. In E. Fromm. (1973) The crisis of psychoanalysis: essays on Freud, Marx and social psychology. Penguin Books, Harmondsworth. pp. 68-84.

Gilburt, H., Slade, M., Bird, V., Oduola, S., Craig, T. (2013) Promoting recovery-oriented practice in mental health services: a quasi-experimental mixed-methods study. BMC 
Psychiatry, vol 13, p 167. Available at: www.biomedcentral.com/1471-244X/13/167 (accessed 05 February 2015).

Grant, A., Biley, F. \& Walker, H. (2011) Our encounters with madness. PCCs Books, Rosson-Wye.

Happell, B., Platania-Phung, C., \& Scott, D. (2014). Proposed nurse-led initiatives in improving physical health of people with serious mental illness: a survey of nurses in mental health. Journal of Clinical nursing, 23, 7-8, 1018-1029.

Hopton, J. (1997) Towards a critical theory of mental health nursing. Journal of Advanced Nursing, 25, 3, 492-500.

Ingleby, D. (1985) Professionals as Socialisers: the 'Psy-Complex'. In A. Scull \& S. Spitzer (Eds.) Research in law, deviance and social control. Jai Press, New York. pp. 79-109.

Ion, R. \& Lauder, W. (2015) Willis and the generic turn in nursing. Nurse Education Today, DOI: http://dx.doi.org/10.1016/j.nedt.2015.03.016

Katsakou, C. and Priebe, S. (2007) Patient's experiences of involuntary hospital admission and treatment: A review of qualitative studies. Epidemiologia E Psichiatria Sociale, 16, 2, $172-178$ 
Katsakou, C., Rose, D., Amos, T., Bowers, L., McCabe, R., Oliver, D. and Priebe, S. (2012) Psychiatric patients' views on why their involuntary hospitalisation was right or wrong: a qualitative study. Social Psychiatry and Psychiatric Epidemiology, 47, 7, 1169-1179.

Keating, F., Robertson, D., McCulloch, A. \& Francis, E. (2002) Breaking the circles of fear: A review of the relationship between mental health services and African and Caribbean communities. Sainsbury Centre for Mental Health, London.

Latoo, J., Mistry, M. \& Dunne, F. (2013) Physical morbidity and mortality in people with mental illness. British Journal of Medical Practitioners, 6, 3, a621

Leucht, S., Burkard, T., Henderson, J. et al (2007) Physical illness and schizophrenia: a review of the literature. Acta Psychiatrica Scandinavica, 116, 317-33.

Lintern, S. (2014) Lord Willis Interview. Health Service Journal, 11 December, http://www.hsj.co.uk/news/exclusive-lord-willis-reveals-plans-for-the-future-of-nurseeducation/5077621.article

MacCallum, E. J. (2002) Othering and psychiatric nursing. Journal of Psychiatric and Mental Health Nursing, 9, 87-94.

Marx, K. (1844) Economic and political manuscripts. In McLennan, D. (1977) Karl Marx: Selected Writings. Oxford University Press, Oxford. 
McAllister, M., Happell, B., \& Flynn, T. (2014) Learning essentials: What graduates of mental health nursing programmes need to know from an industry perspective. Journal of Clinical Nursing, 23, 3449-3459.

McAndrew, S., Chambers, M., Nolan, F., Thomas, B. \& Watts, P. (2014) Measuring the evidence: Reviewing the literature of the measurement of therapeutic engagement in acute mental health inpatient wards. International Journal of Mental Health Nursing, 23, 212-220.

McKeown, M. (1995) The Transformation of Nurses' Work? Journal of Nursing Management, 3, 2, 67-73.

McKeown, M. \& Carey, L. (2015) Editorial. Democratic leadership: a charming solution for nursing's legitimacy crisis. Journal of Clinical Nursing, 24, 315-317.

MHNAUK (2014) Our response to the Health Service Journal exclusive on the future of nurse education.

http://mhnauk.swan.ac.uk/ResponsePapers/MHNAUKresponsetoHSJarticle2014.pdf

MHNAUK (2015) Press Release - MHNAUK Response to Shape of Caring Review http://mhnauk.swan.ac.uk/Responses.htm accessed 21.03.15

Middleton, J. (2015) Editors Comment: Nurses must maximise use of Shape of Caring. Nursing Times http://www.nursingtimes.net/opinion/editors-comment/nurses-must-maximiseuse-of-shape-of-caring/5083361.article accessed 21.03.15

Miller, P. \& Rose, N. (eds) (1986) The Power of Psychiatry. Cambridge: Polity Press. 
Mosher, L. (1999) Soteria and other alternatives to acute psychiatric hospitalization: a personal and professional review. Journal of Nervous and Mental Disease, 187, 142-9.

Moncrieff, J., Cohen, D. \& Porter, S. (2013) The psychoactive effects of psychiatric medications: the elephant in the room. Journal of Psychoactive Drugs, 45, 409-415. http://www.ncbi.nlm.nih.gov/pmc/articles/PMC4118946/

Naylor C., Parsonage M., McDaid D., Knapp M., Fossey M., Galea A. (2012). Long-term conditions and mental health: the cost of co-morbidities. The King's Fund, London.

Newnes, C., Holmes, G., \& Dunn, C. (Eds.) (1999). This is madness: A critical look at psychiatry and the future of mental health services. PCCS Books, Ross-on-Wye.

Newnes, C., Holmes, G., \& Dunn, C. (Eds.) (2001) This is madness too: Critical perspectives on mental health services. PCCS Books, Ross-on-Wye.

Pilgrim, D. (2008) "Recovery" and current mental health policy. Chronic Illness, 4, 295-304

Pilgrim, D. (2012) It's complicated: the ethical ramifications of suicide. Clinical Psychology Forum, 237, 51-54.

Pilgrim, D., \& McCranie, A. (2013). Recovery and Mental Health: A Critical Sociological Account. Palgrave Macmillan, Basingstoke. 
Piore, M. J., \& Sabel, C. F. (1984). The second industrial divide: possibility for prosperity. Basic Books, New York.

Robson, D. \& Gray, R. (2007) Serious mental illness and physical health problems: a discussion paper. International Journal of Nursing Studies, 44, 457-466

Robson, D., Haddad, M., Gray, R. \& Gournay, K. (2012) Mental health nursing and physical health care: A cross sectional study of nurses' attitudes, practice and perceived training needs for the physical health care of people with severe mental illness. International Journal of Mental Health Nursing, 22, 409-417.

Rogers, A. and Pilgrim, D. (2014) A Sociology of Mental Health and Illness. Fifth Edition. Maidenhead: Open University Press.

Rogers, A., Pilgrim, D., \& Lacey, R. (1993) Experincing psychiatry: user's views of services. Macmillan, Basingstoke.

Royal College of Psychiatrists (2011) Do the Right Thing: How to Judge a Good Ward. Ten Standards for Adult In-Patient Mental Healthcare. Occasional Paper 79. RCP, London.

Royal College of Psychiatrists (2012). Report of the National Audit of Schizophrenia (NAS) 2012. Healthcare Quality Improvement Partnership, London. 
Royal College of Psychiatrists (2014). Report of the Second Round of the National Audit of Schizophrenia (NAS) 2014. Healthcare Quality Improvement Partnership, London.

Russo, J. \& Beresford, P. (2014) 'Between exclusion and colonisation: seeking a place for mad people's knowledge in academia.' Disability and Society (ahead-of-print), 1-5. DOI:10.1080/09687599.2014.957925

Sapey, B. (2013) Compounding the trauma: the coercive treatment of voice hearers. European Journal of Social Work, 16, 3, 375-390.

Seikkula, J., Alakare, B., and Aaltonen, J. (2011) The Comprehensive Open-Dialogue Approach in Western Lapland: II. Long-term stability of acute psychosis outcomes in advanced community care. Psychosis, 3, 3, 192-204.

Seikkula, J., \& Olson, M. E. (2003) The open dialogue approach to acute psychosis: Its poetics and micropolitics. Family Process, 42, 3, 403-418.

Sibitz, I., Scheutz, A., Lakeman, R., Schrank, B., Schaffer, M and Amering, M. (2011) Impact of coercive measures on life stories: qualitative study. British Journal of Psychiatry, 199, 3, 239-244.

Skills for Health (2006) Delivering a Flexible Workforcet to Support Health and Health Services - The Case for Change. Skills for Health, Bristol. 
Spandler, H. \& Stickley, T. (2011) No hope without compassion: the importance of compassion in recovery-focused mental health services. Journal of Mental Health, 20, 555566.

Szmukler, G. \& Rose, N. (2013) Risk assessment in mental health care: Values and costs. Behavioral Sciences \& the Law, 31, 1, 125-140.

Taylor, F. W. (1911) The Principles of Scientific Management. Harper \& Brothers, New York. UKCC (1999) Fitness to practice. UKCC, London.

Whittaker, R. (2010) Anatomy of an Epidemic: Magic Bullets, Psychiatric Drugs and the Astonishing Rise of Mental Illness in America. Broadway Books, New York.

Whittington, D. \& McLaughlin, C. (2000) Finding time for patients: an exploration of nurses' time allocation in an acute psychiatric setting. Journal of Psychiatric and Mental Health Nursing, 7, 259-268.

Wilkinson R. \& Pickett K. (2009) The Spirit Level: Why Greater Equality Makes Societies Stronger. Allen Lane, London.

Willis, P. (Lord) (2015) Raising the bar. Shape of caring: a review of the future education and training of registered nurses and care assistants. Health Education England, London.

Witz, A. (1990) Patriarchy and professions: The gendered politics of occupational closure. Sociology, 24, 675-690. 
Wyder, M., Bland, R. and Crompton, D. (2013) Personal recovery and involuntary mental health admissions: The importance of control, relationships and hope. Scientific Research Open Access, 5, 3A, 574-581. 